\title{
Consumer Preference for Foxtail and Little Millets in North Eastern Region of Karnataka
}

\author{
Ambana Gouda Durgad", Amrutha T Joshi and G.M. Hiremath \\ University of Agricultural Sciences, Raichur, Karnataka, India \\ *Corresponding author: agdurgad@gmail.com (ORCID ID: 0000-0003-2309-1139)
}

Received: 24-01-2021

Revised: $28-02-2021$

Accepted: 04-03-2021

\begin{abstract}
Finger millet was the most consumed among the urban consumers with $3.00 \mathrm{~kg}$ per month while other millets equally being consumed by the urban consumers, while foxtail millet, finger millet and little millet were consumed by rural consumers with higher consumption of foxtail millet. The monthly household food expenditure among the urban consumers, expenses made on groceries (40.21 percentage), expenditure on millet (15.33 percentage), purchasing minor millets were as nutritional and health benefits (96.67 percentage) followed by doctor's advice (53.33 percentage) similarly, traditional staple food (93.33 percentage) followed by own production (80.00 percentage) for rural households. For each respondent, the part-worth's were estimated using OLS regression analysis, rural consumers also found price to be the most important attribute accounting 26.11 per cent of relative importance, gaining awareness among consumers in consumption of millets for nutritional value and health benefits is improving gradually.

Highlights

( U Urban consumers consumed more types of millets when compared to rural consumers even at a higher price. Likewise rural consumers depended more on locally available or millets produced on their own field.
\end{abstract}

Keywords: Consumer preference, millets, conjoint analysis

Millets are important crops in the semi-arid tropics of Asia and Africa (especially in India and Nigeria), Millets are round-shaped cereal seeds, naturally available in many colours and sizes, depending on the variety. Foxtail millet (Setaria italica (L.) P. Beauv.) has been identified as a major millet in terms of worldwide production, as it is the sixth highest yielding grain (Nitya \& Keshavan, 2017) It is one of the easily cultivated cereal grains belonging to the Setaria genus of Poaceae family and subfamily Panicoideae. Foxtail millet is one of the world's oldest cultivated crops with its earliest archaeological remains found in northern China, dating back some 7400-7935 years. The millet family of plants occur naturally in arid areas and semi-arid areas such as central Africa and Asia with 97.00 per cent of millet production in developing countries. The millets have received less attention with regard to their improvement, withstanding their relative importance and future potential for increasing food production in both the developing and developed regions of the world. Millets such as ragi and foxtail have seen a new-found demand in recent years with health-conscious consumers waking up to their nutritional benefits as lifestyle diseases rise, the production of such Nutri-cereals has witnessed a volatile trend. Millets are good sources of micronutrients, vitamins and minerals and hence they are important food staples in human history. Millets are used for food, feed, forage and

\footnotetext{
How to cite this article: Durgad, A.G., Joshi, A.T. and Hiremath, G.M (2021). Consumer Preference for Foxtail and Little Millets in North Eastern Region of Karnataka. Economic Affairs, 66(1): 101-108.

Source of Support: None; Conflict of Interest: None (c) क्
} 
industrial or other products in tropical or temperate regions. These crops are still the principal sources of energy, protein, vitamins and minerals for millions of the poorest people. Millets are grown in harsh environments where other crops grow or yield poorly. Millet consumption as direct food had significantly declined over the past three decades (Vilas, 2018). The decline in demand has led to the decline in millets production considerably in India. Neglected and underutilized species are considered 'minor' in terms of global trade and the research attention that they have received. Millets are grown in about 21 States. There is a major impetus in Karnataka, Andhra Pradesh, Tamil Nadu, Kerala, Telangana, Uttarakhand, Jharkhand, Madhya Pradesh and Haryana. There is a scope for millets in Manipur, Meghalaya and Nagaland, as it is a major staple diet for the tribes (Vilas, 2018). With the modern agriculture placing more and more emphasis on high yielding crops and their varieties for increasing production, productivity and profit, the cultivation of small millets is being abandoned. Although, minor millets are nutritionally superior, the non-availability of refined and processed millets in ready-to-use form has restricted their use on a larger scale (Shanthakumar et al. 2010). Millet grains offer many opportunities for value addition and diversified utilization which may create income enhancement opportunities for the farmers.

\section{METHODOLOGY}

Consumer's data related to millets consumption (foxtail millet and little millet) were collected from 60 respondents using random sampling method. Among 60 respondents, 30 were from rural areas producing foxtail millet and little millet while remaining 30 respondents were from urban area of the selected districts of the study area. Rural respondents were surveyed from Ballari, Koppal and Raichur districts while urban respondents were surveyed from Ballari, Koppal and Raichur city due to research and INSIMP (Initiative for nutritional security trough intensive millets) scheme in ICARKVK at Gangawati, Hagri and Raichur and also presence of UAS, Raichur where lot of millet based products processing, value addition and marketing are carried out.

\section{CONJOINT ANALYSIS}

Conjoint analysis is a multivariate technique that is commonly used to determine the relative importance of a product's multidimensional features, and it is particularly well suited for measuring human perceptions and preferences (Green \& Wind, 1975; Louviere, 1988). The analysis refers to any decomposition method that estimates the structure of buyers' preferences for a product's features, given the buyers' overall evaluations of a set of products described by levels of specific features (Green \& Srinivasan, 1978).

Using conjoint analysis, a researcher can analyse a heterogeneous product market and obtain results that can be highly disaggregated into homogeneous groups of buyers. Alternatively, aggregating results for buyers who have similar preference or utility functions can be useful in modifying current products or services and in designing new ones for selected market segments (Green \& Wind, 1975).

The additive conjoint model was used in this study. The model has been formulated as:

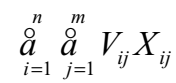

Where,

$Y=$ Consumers $^{\prime}$ overall evaluation of the Foxtail millet and Little millet.

$V_{i j}=$ Part worth associated with ' $j$ ' $(1,2,3$, $m)$ of attributes, ' $i$ ' $(1,2, \ldots \ldots \ldots \ldots, n)$ the attributes are given in Table 3.2 for consumers.

$X_{i j}=$ Dummy variable representing the preference of the $j^{\text {th }}$ level of $i^{\text {th }}$ attribute.

For this study, profile describing alternatives was constructed by combining levels of six attributes. The attributes and their levels were identified through discussions with the consumers during the survey and also on consultation with marketing and food science specialists.

The explanatory variables specified in the model are education (years), income of the consumers (₹) farm experience (years), yield $(q)$ drought tolerant (dummy; tolerant $=1$, susceptible $=0$ ), colour of foxtail and little millet (dummy; yellow $=1$, white $=0)$, taste (dummy; sweet $=1$, pungent $=0$ ), nutritional quality (dummy; maintain same $=1$, further improve $=0$ ), price (dummy; low $=1$, high 
$=0$ ), grain size (dummy; small $=1$, bold $=0$ ) and aroma (dummy; natural $=1$, non-scented $=0$ ).

The data was tabulated, coded and analysed using GRETL statistical computer programme. The dependent variable willingness to pay (WTP) was regressed on selected explanatory variables to identify explanatory variables which highly influence the producers and consumers WTP for new variety.

The logistic regression coefficient $\left(\beta_{i}\right)$ can be used to estimate adjusted odds ratios for each of the independent variables in the model.

\section{Tabular Presentation}

Descriptive analysis was employed to compile the socio-economic status, cost and returns of foxtail millet and little millet cultivation, labour use pattern and marketed surplus. In order to facilitate interpretation of findings.

\section{RESULTS}

\section{Socio-Economic Profile of Rural and Urban Consumers in the Study AREA}

The Socio-economic characteristics of sample consumers are presented in Table 1. The sample consumers are categorised into urban consumers and rural consumers. Data was enumerated from a total sample of 60 consumers comprising of 30 urban and 30 rural consumers. Majority of the urban consumers were middle aged between 35 to 55 years while it was 60.00 per cent among the rural consumers. It was interesting to note that majority ( 95.00 percentage) of the millet consumers were literates in both urban and rural areas. The average family size was five members for urban and eight for rural consumers. Here middle aged consumers (75.00 percentage) had taken a loin share in consumption of millets due to its nutritional awareness. And it is more in urban consumers because of doctor's advice and young age (15.00 percentage) and old aged (10.00 percentage) consumers are negligible tastelessness and heard to digest.

\section{Monthly Average Consumption of Millets by Urban and Rural Consumers}

The monthly average consumption of millets among the urban and rural consumers are studied and indicated in Table 2. The millets such as foxtail millet, little millet, finger millet, kodo millet

Table 1: Socio-Economic Profile of Urban and Rural Consumers

\begin{tabular}{|c|c|c|c|c|c|c|c|}
\hline \multirow{2}{*}{$\begin{array}{l}\text { Sl. No. } \\
\text { I }\end{array}$} & \multirow{2}{*}{$\begin{array}{l}\text { Particulars } \\
\text { Age }\end{array}$} & \multicolumn{2}{|c|}{ Urban consumers $(n=30)$} & \multicolumn{2}{|c|}{ Rural consumers $(n=30)$} & \multicolumn{2}{|c|}{ Overall $(n=60)$} \\
\hline & & Frequency & Percentage & Frequency & Percentage & Frequency & Percentage \\
\hline A & Young age (<35 years) & - & - & 09 & 30.00 & 09 & 15.00 \\
\hline B & Middle age (35-55 years) & 27 & 90.00 & 18 & 60.00 & 45 & 75.00 \\
\hline C & Old age ( $>55$ years) & 03 & 10.00 & 03 & 10.00 & 06 & 10.00 \\
\hline Total & & 30 & 100.00 & 30 & 100.00 & 60 & 100.00 \\
\hline II & Education level & & & & & & \\
\hline A & Illiterate & - & - & 03 & 10.00 & 03 & 5.00 \\
\hline B & Primary & - & - & 17 & 57.00 & 17 & 28.00 \\
\hline $\mathrm{C}$ & High school & - & - & 07 & 23.00 & 07 & 12.00 \\
\hline $\mathrm{D}$ & Pre-University & 04 & 13.00 & - & - & 04 & 7.00 \\
\hline $\mathrm{E}$ & Degree & 12 & 40.00 & 03 & 10.00 & 15 & 25.00 \\
\hline $\mathrm{F}$ & Post-graduation & 14 & 46.00 & - & - & 14 & 23.00 \\
\hline Total & & 30 & 100.00 & 30 & 100.00 & 60 & 100.00 \\
\hline III & Average family size & & & & & & \\
\hline A & Men & 2.00 & 40.00 & 3.00 & 37.50 & 2.50 & 38.00 \\
\hline B & Women & 1.00 & 20.00 & 2.00 & 25.00 & 1.50 & 23.00 \\
\hline $\mathrm{C}$ & Children & 2.00 & 40.00 & 3.00 & 37.50 & 2.50 & 38.00 \\
\hline Total & & 5.00 & 100.00 & 8.00 & 100.00 & 6.50 & 100.00 \\
\hline IV & Average family annual income & 1182948 & & 53133 & & 618040 & \\
\hline
\end{tabular}


Table 2: Monthly Average Consumption of Millets by Urban and Rural Consumers

\begin{tabular}{llllllll}
\hline \multirow{2}{*}{ S1. No. } & \multirow{2}{*}{ Millets } & \multicolumn{3}{c}{ Urban consumers $(\mathbf{n}=\mathbf{3 0})$} & \multicolumn{3}{c}{ Rural consumers $(\mathbf{n}=30)$} \\
\cline { 2 - 7 } & & Quantity $(\mathbf{k g})$ & Price $/ \mathbf{k g}$ & Value (₹) & Quantity $(\mathbf{k g})$ & Price / $\mathbf{k g}$ & Value (₹) \\
\hline 1 & Foxtail millet & 2.30 & 56.00 & 128.80 & 7.15 & 36.00 & 257.40 \\
2 & Little millet & 2.10 & 86.00 & 180.60 & 1.10 & 60.00 & 66.00 \\
3 & Finger millet & 2.80 & 54.00 & 151.20 & 2.65 & 45.00 & 119.25 \\
4 & Kodo millet & 1.80 & 126.00 & 226.80 & - & - & - \\
5 & Brown top millet & 2.00 & 210.00 & 420.00 & - & - & - \\
\hline
\end{tabular}

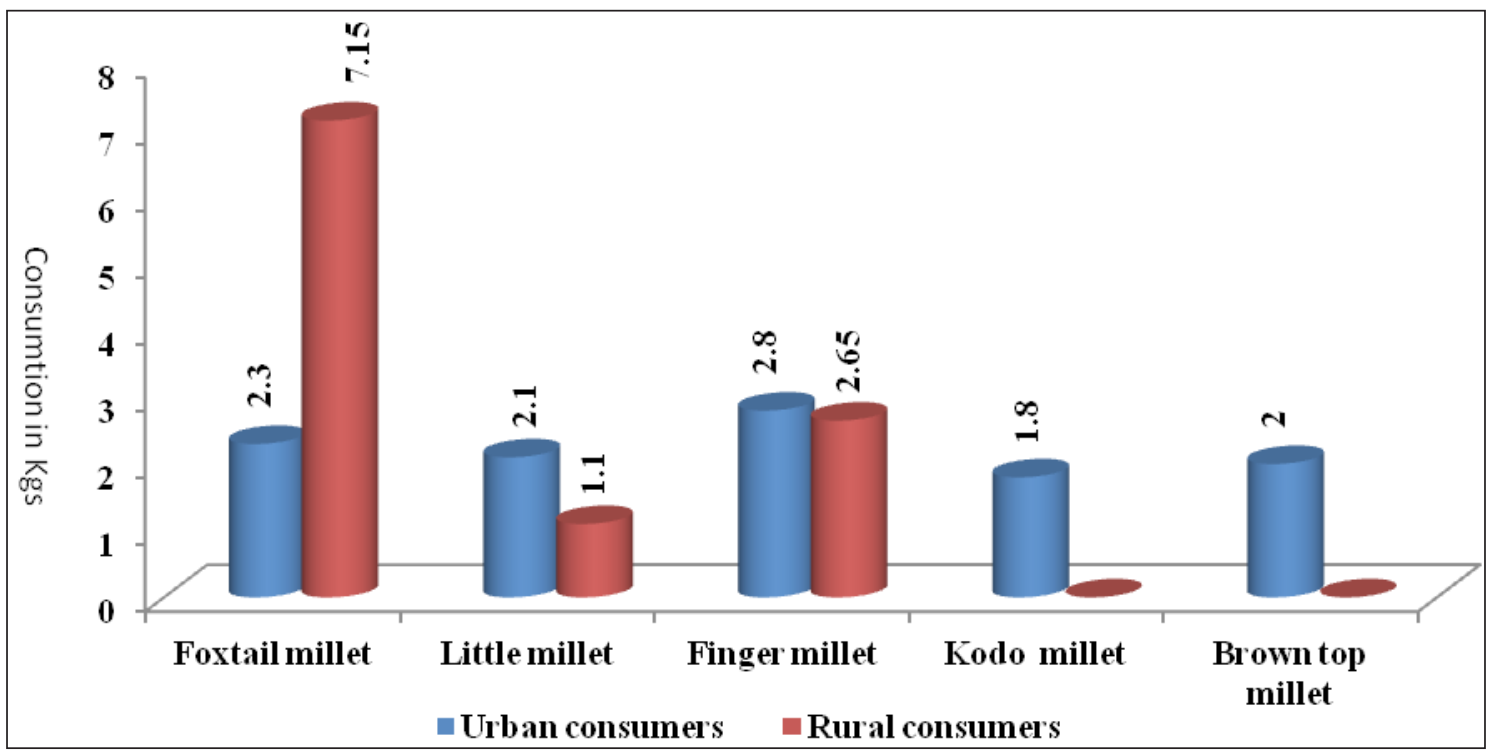

Fig. 1: Monthly Average Consumption of Millets by Urban and Rural Consumers

and brown top millet were the different millets consumed. Finger millet was the most consumed among the urban consumers with $2.80 \mathrm{~kg}$ per month while other millets equally being consumed by the urban consumers, while foxtail millet, finger millet and little millet were consumed by rural consumers with higher consumption of foxtail millet $7.15 \mathrm{~kg} /$ month. In value terms brown top millet ( $₹ 210$ per $\mathrm{kg}$ ) was priced high for urban consumers. The price of millets is low in rural areas since they use millets which are produced by them.

Thus, it can be observed from the Fig. 1 that urban consumers consumed wide verities of millets when compared to rural consumers even at a higher price. Likewise, rural consumers depended more on locally available or millets produced on their own field.

\section{Monthly Household Food Expenditure of Rural and Urban Consumers}

The monthly household food expenditure of rural and urban consumers are presented in Table 3.
The results revealed that the household major expenditures were on groceries, vegetables, milk, fruits, millets, meat and miscellaneous.

Among the urban consumers, expenses made on groceries 40.21 percentage were the major followed by vegetables (15.17 percentage), milk (14.30 percentage) and fruits (6.22 percentage). The total food expenses made by urban consumers were ₹ 7295 of which 15.33 per cent was made on millets which amounted to ₹ 1118. Similarly, in the case of rural consumers, groceries (42.84 percentage) were the major expenditure, followed by milk (15.98 percentage), vegetables (14.99 percentage) and fruits (6.25 percentage). The expenses made toward millets were 8.12 per cent amounting to $₹ 447$. The total expense made toward food by rural consumers was ₹ 5502 which was less than the urban consumers (₹ 7295).

Monthly average consumption and household food expenditure were tabulated in 4.25 and 4.26 respectively. Major share of the expenditure was on groceries. The share of millets in culinary of urban 
Table 3: Monthly Household Food Expenditure of Rural and Urban Consumers

\begin{tabular}{llllll}
\hline \multirow{2}{*}{ S1. No. } & \multirow{2}{*}{ Particulars } & \multicolumn{2}{c}{ Urban consumers (n=30) } & \multicolumn{2}{c}{ Rural consumers (n=30) } \\
\cline { 3 - 6 } & Amount (₹) & Percent & Amount (₹) & Percent \\
\hline 1 & Groceries & 2933 & 40.21 & 2357 & 42.84 \\
2 & Vegetables & 1107 & 15.17 & 825 & 14.99 \\
3 & Milk & 1043 & 14.30 & 879 & 15.98 \\
4 & Fruits & 454 & 6.22 & 344 & 6.25 \\
5 & Millets & 1118 & 15.33 & 447 & 8.12 \\
6 & Meat & 340 & 4.66 & 280 & 5.09 \\
7 & Miscellaneous & 300 & 4.11 & 170 & 6.72 \\
\hline Total & & $\mathbf{7 2 9 5}$ & $\mathbf{1 0 0 . 0 0}$ & $\mathbf{5 3 0 2}$ & $\mathbf{1 0 0 . 0 0}$ \\
\hline
\end{tabular}

Table 4: Consumption Pattern of Millet Products Among Urban and Rural Consumers

\begin{tabular}{llllllll}
\hline & & \multicolumn{3}{c}{ Urban consumers $(\mathbf{n}=\mathbf{3 0})$} & \multicolumn{2}{c}{ Rural consumers (n=30) } \\
\cline { 3 - 7 } S1. No. & Millet products & Numbers & Per cent & $\begin{array}{l}\text { Frequency of } \\
\text { consumption }\end{array}$ & Numbers & Per cent & $\begin{array}{l}\text { Frequency of } \\
\text { consumption }\end{array}$ \\
\hline 1 & Millet Rice items & 30 & 100.00 & Daily & 30 & 100.00 & Daily \\
2 & Malt & 11 & 36.67 & Weekly & 13 & 43.33 & Weekly \\
3 & Upma & 20 & 66.67 & Weekly & 8 & 26.67 & Weekly \\
4 & Idli/dosa & 26 & 86.67 & Weekly & 16 & 53.33 & Weekly \\
5 & Sweets & 7 & 23.33 & Weekly & - & - & - \\
6 & Baked products & 15 & 50.00 & Occasionally & - & - & - \\
7 & Snacks & 18 & 60.00 & Occasionally & 2 & 6.67 & Occasionally \\
\hline
\end{tabular}

consumers was 15.33 per cent, and that of rural consumers was 8.12 per cent. Similarly the urban consumers used almost all types of millets but the rural consumers consumed only foxtail, finger and little millets as they were grown in their farms and neighbourhood.

\section{Consumption Pattern of Millet Products Among Sample Consumers}

Consumption pattern of sample consumers for millet products are discussed in Table 4 . Millet rice items such as palav, coloured rice, malt, upma, sweets made out of millets baked products and snacks were the different millet products consumed by both urban and rural consumers. Rice items were consumed on a daily basis by all the consumers while $i d l i / d o s a$ was the next form of the millet consumption by both urban (86.67 percentage) and rural (53.33 percentage) consumers on a weekly basis most of the other products were purchased from retail outlets and hence the rural consumers did not have access to such products and urban consumers occasionally consumed such products.

\section{Source of Information to Consumer on Millet Value Added Products}

The source of information about value added products are presented in Table 5. Consumption of millet based products such as rice item, malt, upma, idli/dosa, sweets, baked products and snacks was noticed among the consumers. News papers/ magazines (43.30 percentage and 26.70 percentage) and Agricultural universities (36.70 percentage and 16.70 percentage) were the major sources of value added products of millets, while elders (40 percentage and 100 percentage) still remained the best source of information especially for day to day prepared rice items among both rural and urban consumers also relied on TV/Radio (56.70 percentage) and food fest/melas (56.70 percentage) for preparation and consumption of some value added products.

Millets rice consumed on a daily basis by both urban and rural consumers while in case of the rural consumers it was the staple food for family along with rice and sorghum, it was consumed by urban consumers because of their health consciousness. 
Table 5: Source of Information for Consumer on Millet Value Added Products (percentage)

\begin{tabular}{|c|c|c|c|c|c|c|c|}
\hline \multicolumn{2}{|c|}{ S1. No. Particulars } & Elders & \multirow[t]{2}{*}{$\begin{array}{l}\text { Newspaper / } \\
\text { Magazine }\end{array}$} & \multirow[t]{2}{*}{$\begin{array}{l}\text { TV / } \\
\text { Radio }\end{array}$} & \multirow[t]{2}{*}{$\begin{array}{l}\text { Friends / } \\
\text { Relatives }\end{array}$} & \multirow[t]{2}{*}{$\begin{array}{l}\text { Mela / } \\
\text { Food fests }\end{array}$} & \multirow[t]{2}{*}{$\begin{array}{l}\text { Agricultural } \\
\text { Universities }\end{array}$} \\
\hline $\mathbf{A}$ & Urban consume & $=30)$ & & & & & \\
\hline 1 & Rice items & 40.00 & 26.70 & 6.70 & 70.00 & 20.00 & 26.70 \\
\hline 2 & Malt & 20.00 & 20.00 & 36.70 & 26.70 & 13.30 & 40.00 \\
\hline 3 & Upma & - & 30.00 & 40.00 & 13.30 & - & 36.70 \\
\hline 4 & Idli/dosa & - & 43.30 & 40.00 & 23.30 & 33.30 & 10.00 \\
\hline 5 & Sweets & - & 43.30 & 56.70 & 6.70 & 20.00 & - \\
\hline 6 & Baked products & - & 26.70 & 13.30 & - & 20.00 & 60.00 \\
\hline 7 & Snacks & - & - & 16.70 & - & 56.70 & 30.00 \\
\hline B & Rural consumer & & & & & & \\
\hline 1 & Rice items & 100.00 & 20.13 & 3.30 & 30.00 & - & 6.70 \\
\hline 2 & Malts & 26.70 & 26.70 & 10.00 & 23.30 & 6.70 & 3.30 \\
\hline 3 & Upma & - & - & 10.00 & 30.00 & 20.00 & 6.70 \\
\hline 4 & Idil/dosa & - & - & 3.30 & 40.00 & - & 16.70 \\
\hline 5 & Sweets & - & - & - & - & - & - \\
\hline 6 & Baked products & - & - & - & - & - & - \\
\hline 7 & Snacks & - & - & - & - & - & - \\
\hline
\end{tabular}

Table 6: Reasons Influencing for the Purchase of Foxtail and Little Millets for Consumption

\begin{tabular}{lllll}
\hline \multirow{2}{*}{ Particulars } & \multicolumn{2}{c}{ Urban consumers $(\mathbf{n}=\mathbf{3 0})$} & \multicolumn{2}{c}{ Rural consumers $\mathbf{( n = 3 0 )}$} \\
\cline { 2 - 5 } & Numbers & Percentage & Numbers & Percentage \\
\hline Delicious taste & 08 & 26.67 & - & - \\
Nutritional and health conscious & 29 & 96.67 & 19 & 63.33 \\
Suggested by friends and relatives & 06 & 20.00 & - & - \\
Own production & - & - & 24 & 80.00 \\
Traditional staple food & - & - & 28 & 93.33 \\
Advice from doctors & 16 & 53.33 & - & - \\
\hline
\end{tabular}

Awareness regarding the millet based breakfast preparation is from electronic and print media and they were consumed once in a week. Results of consumption pattern were similar to the study conducted by Amarapurkar and Banakar (2017).

Sweets, baked products and snacks of millets were consumed occasionally only by the urban consumers. Major source of information regarding these value added products ware also from media and agricultural universities. These results were in line with Kalidas and Mahendran (2017).

\section{Reasons Influencing the Consumption of Foxtail and Little Millets}

It was noticed from the Table 6 that the major factors considered by the urban consumers while purchasing minor millets were as nutritional and health benefits (96.67 percentage) followed by doctor's advice (53.33 percentage) delicious taste in nature (26.67 percentage) and suggestions from friends and relatives (20.00 percentage). Similarly for rural consumers were expressed as traditional staple food (93.33 percentage) followed by own production ( 80.00 percentage) that is produced by household itself and nutritional value and health benefits (63.33 percentage). Urban Consumers bought these products along with the monthly grocery in retail stores or they purchase it whenever they felt to consume these millet products. In case of the rural consumers household itself acts as a producer since majority of the rural respondents consumed as traditional staple food. Nutritional content was major factor for urban consumers which was influencing the purchase as most of the consumers were educated and having health consciousness as well as were aware about the nutritional benefits.

\section{Preference for Millets Among Urban and Rural Consumers}

The important attributes of millet that determine consumer preferences in urban and rural area were 
taste, colour, aroma, nutrition quality, size of grain and price. For each respondent, the part-worth's were estimated using Ordinary Least Squares (OLS) regression analysis. The relative importance of the part-worth functions was compared across different attributes within segments in order to arrive at the relative importance of each attribute. Average partworth's and the relative importance of the attributes for urban and rural area are presented in Table 7.

Among all the attributes of millets studied for urban consumers, price was found to be the most important and first consideration for consumers, accounting for 25.81 per cent of relative importance with low price having the utility of 1.239 . Colour had a strong influence on consumer's preference after price in urban area accounting for 25.34 per cent with yellow having the utility 1.217. The individual utilities for small and bold size grain (21.99 percentage preference) were -1.056 and 1.056, respectively.

Aroma formed the fourth most important factor having a relative importance of 13.31 per cent, with non-scented one having the utility of 0.639 . Nutritional quality was the important attribute but the results showed that, the urban consumers gave less importance ( 7.40 percentage) due to higher importance given to price as these millets are to be purchased. Taste had the least important attribute accounting 6.13 per cent of relative importance. In general, consumption of millet in urban areas was relatively lower, compared to rural areas may be due to availability of other food substitutes. Likewise, rural consumers also found price to be the most important attribute accounting 26.11 per cent of relative importance, with low price having the utility of 1.044. Nutrition quality had more influence on consumer's preference after price among rural consumers with a relative importance of 23.05 per cent with 'further improve' having the utility of 0.922 .

Colour was the third most important factor influencing consumer's preference after nutritional quality, accounting 21.25 per cent of relative importance, with yellow having the utility of 0.85 . While, size of grain was less important attribute with relative importance at 7.50 per cent. Taste was least preferred attribute even by rural consumers also (7.36 percentage).

The fit of the additive model to the individual data was good. In case of urban consumers, Pearson's rank correlation value with 0.785 was significant at 1 per cent level, similarly, the Kendall's correlation value with 0.515 was also found to be significant at 10 per cent level. Similar pattern of correlations

Table 7: Consumer Preferences for Foxtail and Little Millets $(n=60)$

\begin{tabular}{|c|c|c|c|c|c|c|}
\hline \multirow{2}{*}{$\begin{array}{l}\text { Sl. } \\
\text { No. }\end{array}$} & \multirow[b]{2}{*}{ Attributes } & \multirow[b]{2}{*}{ Attribute levels } & \multicolumn{2}{|c|}{ Urban consumers $(n=30)$} & \multicolumn{2}{|c|}{ Rural consumers $(n=30)$} \\
\hline & & & Utility & $\begin{array}{l}\text { Relative importance } \\
(\%)\end{array}$ & Utility & $\begin{array}{l}\text { Relative } \\
\text { importance (\%) }\end{array}$ \\
\hline \multirow{2}{*}{1} & \multirow{2}{*}{ Taste } & Pungency & 0.294 & \multirow{2}{*}{6.13} & 0.294 & \multirow{2}{*}{7.36} \\
\hline & & Sweet & -0.294 & & -0.294 & \\
\hline \multirow{2}{*}{2} & \multirow{2}{*}{ Colour } & White & -1.217 & \multirow{2}{*}{25.34} & -0.85 & \multirow{2}{*}{21.25} \\
\hline & & Yellow & 1.217 & & 0.85 & \\
\hline \multirow{2}{*}{3} & \multirow{2}{*}{ Aroma } & Natural & 0.639 & \multirow{2}{*}{13.31} & 0.589 & \multirow{2}{*}{14.72} \\
\hline & & Scented & -0.639 & & -0.589 & \\
\hline \multirow{2}{*}{4} & \multirow{2}{*}{ Nutritional quality } & Maintain same & -0.356 & \multirow{2}{*}{7.40} & -0.922 & \multirow{2}{*}{23.05} \\
\hline & & Further improve & 0.356 & & 0.922 & \\
\hline \multirow{2}{*}{5} & \multirow{2}{*}{ Size of grain } & Small & -1.056 & \multirow{2}{*}{21.99} & -0.3 & \multirow{2}{*}{7.50} \\
\hline & & Bold & 1.056 & & 0.3 & \\
\hline \multirow{2}{*}{6} & \multirow{2}{*}{ Price } & Low & 1.239 & \multirow{2}{*}{25.81} & 1.044 & \multirow{2}{*}{26.11} \\
\hline & & High & -1.239 & & -1.044 & \\
\hline \multicolumn{3}{|c|}{ Total } & 6.50 & 100 & 6.50 & 100 \\
\hline \multicolumn{2}{|c|}{ Correlations } & & Values & & Values & \\
\hline \multicolumn{2}{|c|}{ Pearson's rank correlation } & & $0.785^{* * *}$ & & $0.772^{* *}$ & \\
\hline \multicolumn{2}{|c|}{ Kendall's rank correlation } & & $0.515^{*}$ & & $0.606^{* *}$ & \\
\hline
\end{tabular}

Note: ** Significant at 1 per cent level; **Significant at 5 per cent level; ${ }^{*}$ Significant at 10 per cent level. 
Pearson's rank $\left(0.772^{* *}\right)$ and Kendall's rank $\left(0.606^{* *}\right)$ were observed at 5 per cent level of significance for rural consumers (Table 7). This gives strong confidence in the suitability of the additive model.

The urban and rural consumers would prefer reduction in price of millets rather than taste and aroma because the price of millets was very high compared to other cereals in the market. Consumers were aware of nutritional aspects and expressed to improve further and to reduce sweetness in millets because it was mainly consumed by diabetic patients, people with obesity and health conscious. Colour was also one of the most preferred attribute in which most them preferred yellow because polishing of millets would lead to loss of nutritional value. Consumers also preferred non-scented bold seed for consumption. These results show there is a scope for development of crops. Similar findings were reported by Bellundagi (2016).

\section{CONCLUSION}

Majority of the urban consumers were middle aged between 35 to 55 years while 60.00 per cent among the rural consumers. It was instructing to notice that most of the millet consumers were literates. Urban consumers consumed more types of millets when compared to rural consumers even at a higher price. Likewise, rural consumers depended more on locally available or millets produced on their own field. Major share of the expenditure by both urban and rural consumers was on groceries. The share of millets in culinary of urban consumers was 15.33 percent, and that of rural consumers was 8.12 per cent. Minor millets are neglected in terms of support for both production and promotion, compared to other crops. Since north eastern Karnataka (NEK) is leading producer of foxtail millet (Navane) and now area under little millet (same) is also increasing in the study area. There is opportunity for the economic improvement of millets production, value addition and marketing have done in the area pertained for study.

\section{REFERENCES}

Amarapurkar, S. and Banakar, B. 2017. A case study of consumer preference towards foxtail millet products. Int. J. Com. Business Man., 10(2): 267-270.

Bellundagi, V. 2016. Assessment of production, market competitiveness of ragi in Karnataka: An Economic Analysis. Ph.D Thesis, Univ. Agric. Sci., Bengaluru. Karnataka (India).

Green, P.E. and Srinivasan, V. 1978. Conjoint analysis in consumer research: issues and outlook. J. Cons. Res., 5: 103-123.

Green, P.E. and Wind, Y. 1975. New ways to measure consumers' judgments. Harvard Business Rev., 53: 107-117.

Kalidas, K. and Mahendran, K. 2017. Buying behaviour of consumers towards instant millet based food products. Food Sci. Res. J., 8(2): 196-202.

Nitya, S. and Keshavan, N. 2017. Foxtail millet: properties, processing, health benefits, and uses. Food Reviews Int. pp. 8755-9129.

Shanthakumar, G., Yenagi, N.B., Shekhar, G.C. and Halikatti, S.I. 2010. Food security and income enhancement of rural poor through improved production technology and value addition of nutritious small millets: Northern Karnataka. Minor Millets in South Asia, 5: 69-106.

Vilas, T. 2018. From green revolution to millet revolution, Indian Institute of Millets Research, Hyderabad, The Hindu, March 26, pp. 3-4. 